\title{
FDI and Intellectual Property Protection in China: A Game Theory Perspective
}

\author{
Dong-Mei Lee, Lee-Yuan Wang, Yue Wang, and Dai-Jiao Zhou
}

\section{ABSTRACT}

The large-scale spread of R\&D activities by MNCs to investment host countries is a new phenomenon of globalization in the past ten years. For the host country, especially a developing host country such as China, how to promote the spillover effect of TNC research and development institutions on the host country and curb its crowding-out effect is a new topic. This paper analyzes the $R \& D$ strategy adopted by transnational corporations in China. We explain the relationship between the strength of intellectual property protection in China and the choice of the organization form of $R \& D$ activities by transnational corporations with game theory and proves the relationship between the two with data. Finally, policy implications are proposed for the trend of sole proprietorship of $R \& D$ activities of transnational corporations.

Keywords: FDI; Intellectual property protection; R\&D.

\author{
Submitted : October 23,2021 \\ Published: December 05, 2021 \\ ISSN: $2507-1076$ \\ DOI: $10.24018 / \mathrm{ejbmr} .2021 .6 .6 .1162$ \\ Dong-Mei Lee * \\ School of Economics and Management, \\ Shanxi University, Taiyuan, P.R. China. \\ (e-mail: lidm@ ${ }^{\circledR}$ su.edu.cn) \\ Lee-Yuan Wang \\ School of Economics and Management, \\ Shanxi University, Taiyuan, P.R. China. \\ (e-mail: 18035668877@163.com) \\ Yue Wang \\ School of Economics and Management, \\ Shanxi University, Taiyuan, P.R. China. \\ (e-mail: 1911641270@qq.com) \\ Dai-Jiao Zhou \\ School of Economics and Management, \\ Shanxi University, Taiyuan, P.R. China. \\ (e-mail: zhoudaijiao2021@163.com) \\ *Corresponding Author
}

\section{INTRODUCTION}

In the 1990s, the global shift in innovation activities of multinational corporations began to receive attention by academics. Vernon (1966) points out in its product life cycle theory that innovation ability is the driving force for the development of MNCs, which gain a sustainable competitive advantage by "internationally progressive transfer of innovative products". Unfortunately, for reasons of competitive advantage in the global market, Vernon's product cycle theory may no longer be applicable to explain the globalization of MNC R\&D activities, i.e., the increasing number of MNCs locating their R\&D activities in other foreign countries, including developing countries considered to be relatively technologically disadvantaged, whose role is usually to develop new products to meet the needs of local or world markets.

From the mid-1980s to the early 1990s, major multinational companies poured into China, and most chose to set up offices and invest in factories. After the mid-1990s, it has become a new trend for multinational companies to set up R\&D institutions in Beijing. In 1994, Northern Telecom co-founded the Nortel-Nortel Research and Development Center in cooperation with Beijing University of Posts and Telecommunications, the first attempt by multinational companies to set up R\&D facilities in China. Since then, multinational companies began to set up R\&D institutions in China. The momentum is rapid. Especially in 1998, there was the peak of multinational companies setting up R\&D institutions in Beijing. Procter and Gamble, Lucent-Bell Labs, Nokia, Microsoft, and other large R\&D institutions were established at that time. In June 1999, the Beijing Municipal Government issued the Interim Regulations on Beijing's Encouragement of the Establishment of Research and Development Institutions in Beijing, which is the first local regulation in China specifically for multinational companies in the R\&D institutions, and has become an important policy factor for multinational companies to increase their investment in Beijing R\&D. Beijing's policy of encouraging multinational companies to set up $R \& D$ institutions in Beijing has led to a second investment boom, with multinational companies such as Panasonic, VIA and Toshiba. In 2004, China ushered in a new round of foreign investment to set up R\&D centers. First in April, Ericsson CEO Sven Kai announced the opening of a new telecommunications R\&D center in Chengdu; then in May, Siemens CEO Dr. Feng Bile announced in Shanghai that he had started to build a R\&D center at the highest level in Beijing, China. Then in May, Nokia Chairman and CEO Ollila said he would set up a CDMA R\&D facility in Beijing and a postdoctoral research station for Nokia. In his 9th trip to China, Microsoft Chairman and Chief Software Designer 
Robert Gates promised that Microsoft would upgrade the level of its R\&D center in China, which would be as efficient as Microsoft's R\&D center in the United States and Europe within five years. As a major step in the global strategy of multinational companies, the wholly owned R\&D center or technology development center established in China is a branch of the global R\&D network established by the top leadership of multinational companies and directly managed by the company's headquarters and is the core research force of multinational companies in China. IBM, SUN, Panasonic, Nokia, Procter and Gamble, Ericsson, Microsoft, and other world's largest multinational companies have set up a wholly owned R\&D organization in China. Such R\&D institutions are closely linked to the headquarters of multinational companies but are relatively weakly connected to their companies in China, and their main task is to study the key technologies needed for the long-term development of the company.

Fundamentally, R\&D activities are still related to the spillover effects of technology and knowledge (AzmanSainiet al., 2010; Long et al., 2018). Teece (1997) found that although the United States multinational companies have expanded $R \& D$ activities to the world, but mainly in the area of applied R\&D. Basic R\&D activities are still located in the home country. To a large extent, the aim of such activities is to avoid the leakage of technology and knowledge (Teece, 1997). In essence, it is the problem of appropriability of the technology and knowledge. Teece \& Pisano (1998) noted that the appropriability of benefits arising from technology and knowledge depended on two factors, the degree to which intellectual property rights protected, and the extent to which technology and knowledge itself could be replicated.

TABLE I: APPROPRIABILITY REGIME

\begin{tabular}{|c|c|c|c|}
\hline \multirow[t]{3}{*}{$\begin{array}{l}\text { The degree to which } \\
\text { intellectual property } \\
\text { rights protected }\end{array}$} & & \multicolumn{2}{|c|}{$\begin{array}{l}\text { The extent to which } \\
\text { technology and knowledge } \\
\text { itself could be replicated }\end{array}$} \\
\hline & & Ease & Difficult \\
\hline & $\begin{array}{l}\text { Loose } \\
\text { Strict }\end{array}$ & $\begin{array}{c}\text { Weak } \\
\text { Moderate }\end{array}$ & $\begin{array}{l}\text { Moderate } \\
\text { Strong }\end{array}$ \\
\hline
\end{tabular}

Source: D. J. Teece, G. Pisano. Collaborative Arrangement and Global Technology Strategy, Research on Technology Innovation, Management and Policy, In Selected works of David. J. Teece, D. J. Teece, Edward Elgar Publishing Limited, pp. 561-590, 1998.

As we can see from Table I, one extreme is that the appropriability is weak when intellectual property protection is relatively loose and the technology itself is easily replicated. In the other two cases, appropriability is between the two extremes mentioned above. When MNCs consider the organization of research and development activities (e.g., subcontracting, wholly owned subsidiaries, joint ventures, technology alliances, cooperation with universities, etc.), they are bound to safeguard their interests to the maximum extent from the nature and legal point of view of the technology itself.

In terms of the investment method and equity structure of R\&D institutions, the R\&D institutions set up by multinational companies in China are mainly wholly owned, such as Motorola's more than 100 research centers in China are wholly owned, and IBM, Fujitsu, Bayer, Intel, Siemens, Ericsson, Lucent and other multinational companies have set up wholly owned R\&D institutions in China. Multinational companies set up wholly owned R\&D facilities primarily for strategic reasons such as preventing technology spillovers, extending technology revenue periods, and strengthening head office control over global R\&D activities. Another important form of research and development institutions of multinational corporations in China is the cooperation and development with Chinese universities and research institutions, but the final results of cooperation of transnational corporations generally put forward intellectual property requirements.

\section{ANALYSIS WITH GAME THEORY}

One of the main obstacles to multinationals investing in China is that China's intellectual property protection is inadequate. MNCs are also often concerned about infringement of their intellectual property rights by Chinese partners in setting up joint ventures, such as the oftencontentious period of protection of patents in technology transfer agreements, where multinationals typically require longer periods (at least 20 years) and are allowed only 10 years before the Patent Law was amended in 2000. According to the relevant research reports, multinational companies engaged in R\&D activities in China, they must consider the issue of technical confidentiality and the benefits of technological leadership, so they tend to adopt the sole proprietary of the equity, of which they often chose foreigncontrolled joint ventures, accounting for $52.6 \%$ of the total sample enterprises. Foreign-owned and foreign-controlled enterprises accounted for $76.1 \%$. The results show that multinational companies with $\mathrm{R} \& \mathrm{D}$ activities tend to adopt the equity structure which can be used to control the enterprises. The more technology-leading companies are, the more inclined they are to take the form of sole proprietorship. Therefore, the rise of foreign investment in R\&D in Beijing has promoted the development of wholly foreign direct investment to a certain extent.

Regionally, in 2002, Beijing absorbed a total of US\$2.81 billion in contract foreign investment, of which US\$781 million was absorbed by joint venture, US $\$ 412$ million was absorbed by cooperative contract foreign investment, and US $\$ 1,538$ million was absorbed by way of sole proprietorship, accounting for $54.7 \%$ of the total contract foreign investment. In the same year, Beijing actually utilized foreign capital of US $\$ 1.79$ billion, of which US\$552 million was actually utilized by joint venture, US\$299 million was actually utilized by cooperative mode, and US $\$ 941$ million was actually utilized by means of sole proprietorship, accounting for $53.6 \%$ of all actual utilization of foreign capital. Whether it is contract foreign capital, or the actual use of foreign capital, the sole proprietorship mode exceeds the sum of joint venture and cooperation mode. The establishment of wholly foreign-owned enterprises has become the main way of foreign direct investment in Beijing. The above facts show that the development of foreign direct investment in Beijing has shown a trend of "sole proprietorship", wholly owned enterprises will become the main form of foreign direct investment in Beijing in the coming period. 


\section{A. Game that Is Implemented without the Supervision of the third PARTY}

Assume that, (1) Game participants in the market are multinational $\mathrm{M}$ and host government $\mathrm{H}$; (2) MNCs are free to choose how to invest if the host Government does not impose restrictions on policies and regulations; (3)When MNCs take the form of sole proprietorship and the host country's intellectual property protection is weak, all the rents it generates from $\mathrm{R} \& \mathrm{D}$ activities in the host country are shared between MNCs and host countries; (4)When the host government's intellectual property protection is strong, transnational corporations have a strong incentive to invest in $\mathrm{R} \& \mathrm{D}$, which can objectively increase the total rent to be shared;(5)In the case of the host government's unconstrained form of R\&D investment organization of MNCs, MNCs may adopt at least two forms of sole proprietorship and joint venture contract;(6)When intellectual property protection is strong, multinational companies can always obtain more benefits under sole proprietorship than joint ventures. According to the above analysis, whether the host Government's intellectual property protection is weak or strong, in order to avoid technological innovation brought about by rents by the host government with an opportunistic tendency to seize, and to strengthen control over research and development results, MNCs always tend to take a sole proprietorship approach. Accordingly, the game takes the form of the following (See Table II):

TABLE II: PAYOFF MATRIX FOR GAME THAT IS IMPLEMENTED WITHOUT THE SUPERVISION OF THE THIRD PARTY

\begin{tabular}{|c|c|c|c|}
\hline & \multicolumn{3}{|c|}{ Host Country $(\mathrm{H})$} \\
\hline \multirow{3}{*}{$\operatorname{MNCs}(\mathrm{M})$} & & $\begin{array}{c}\text { Weak } \\
\text { intellectual } \\
\text { property } \\
\text { protection }\end{array}$ & $\begin{array}{c}\text { Strong intellectual } \\
\text { property } \\
\text { protection }\end{array}$ \\
\hline & $\begin{array}{c}\text { Sole } \\
\text { proprietorship }\end{array}$ & $(m, n)$ & $(p, q)$ \\
\hline & Joint Ventures & $(q, p)$ & $(t, t)$ \\
\hline
\end{tabular}

Note: The first number in parentheses represents the payoff for transnational corporations and the second figure represents the payoff for the host Government. The relationships between the numbers in the game are: $p>m>t>q>n$.

The rationality of the above-mentioned game structure lies in the fact that when a MNCs adopt a sole proprietorship approach, it is bound to receive a greater payoff than it would have in the case of weaker intellectual property protection in the host country when the host Government's intellectual property protection is stronger $(p>m)$; the opposite is true for host Governments $(n>q)$; when a multinational company adopts a joint venture approach, its rent is largely appropriated by the host government when the host government's intellectual property protection is weak, while in the case of strong intellectual property protection, the MNC's rights can be protected and the rent generated by its R\&D can be obtained, and the host government will benefit from cooperation with the multinational company. Therefore, in this case, both parties receive the largest total rent. According to the basic knowledge of game theory, the Nash equilibrium solution of the above-mentioned game is: (sole proprietorship, weak intellectual property protection).

\section{B. Game that Is Implemented with the Supervision of the Third Party}

If there is a problem with third-party implementation, the basic structure of the game will change. When third-party oversight exists, the host Government is punished if its intellectual property protection is weak. If the penalty is $\mathrm{s}$, the game above becomes the following (See Table III):

TABLE III: PAYOFF MATRIX FOR GAME THAT IS IMPLEMENTED WITH THE SUPERVISION OF THE THIRD PARTY

\begin{tabular}{cccc}
\hline \hline & & $\begin{array}{c}\text { Host Country(H) } \\
\text { Weak } \\
\text { intellectual } \\
\text { property } \\
\text { protection }\end{array}$ & $\begin{array}{c}\text { Strong } \\
\text { intellectual } \\
\text { property } \\
\text { protection }\end{array}$ \\
\cline { 2 - 4 } $\operatorname{MNCs}(\mathrm{M})$ & $\begin{array}{c}\text { Sole } \\
\text { proprietorship }\end{array}$ & $(m, n-s)$ & $(p, q)$ \\
& Joint Ventures & $(q, p-s)$ & $(t, t)$ \\
\hline \hline
\end{tabular}

Note: The first number in parentheses represents the payoff for transnational corporations and the second figure represents the payoff for the host Government. The relationships between the numbers in the game are: $p>m>t>q>n$.

In this case, if (sole proprietorship, weak protection of intellectual property rights) becomes an equilibrium game solution, the conditions must be met: (1) $n-s>q$; (2) $m>q$.The second condition is met automatically. The first condition implies that if the host Government still pays more after paying the penalty than it does in the case of stronger intellectual property protection, it will choose to take a lower level of intellectual property protection. We can see that when the fines paid are high enough, the host Government's "weak intellectual property protection" strategy will not be its optimal strategy. In this case, when the host country adopts a higher level of intellectual property protection, MNCs must adopt a sole proprietorship strategy $(p>m)$. However, from the perspective of developing countries, foreign joint ventures with local enterprises are the most beneficial form of foreign investment, as they facilitate the diffusion and transfer of technology to developing countries. The practice of foreign investment activities in China has proved that joint ventures are rarely possible in $R \& D$ intensive industries. In industries that need research and development support, foreign investors prefer to set up wholly owned enterprises rather than joint ventures. Even in joint ventures, multinationals are careful to retain control of their core technologies. For example, in Japanese and Korean companies, core technologies are usually accessible only to senior technicians in Japan or South Korea, and Chinese technicians are not exposed to these technologies. For host governments in developing countries, the host government would receive more revenue if, as a result, MNCs could be guided to joint ventures in the context of strong intellectual property protection. To take a step back and we can see that even if host countries are unable to do so, how to respond to obtain more from the sole proprietorship of MNCs is a problem that we must face.

On the other hand, (joint venture, strong intellectual property protection) will not be able to become an equilibrium solution, because the Nash equilibrium solution of the two conditions: (1) $t>p-s$ and (2) $t>p$, of which cannot be met.

With China's formal accession to the WTO, the legal 
system of intellectual property rights should also be in line with international standards. The WTO's Agreement on Trade-Related Aspects of Intellectual Property Rights deals with legal and environmental issues affecting international direct investment. This agreement protects a wider range of copyrights, trademarks, industrial design, patents, integrated circuit design, nonpublic information or trade secrets, certain restrictive business practices and anticompetitive practices that impede technology transfer and proliferation than previous agreements on intellectual property rights. China's efforts in intellectual property protection objectively create the conditions for multinational companies to adopt a sole proprietorship approach to R\&D investment in China.

\section{EVIDENCE ON THE RELATIONSHIP BETWEEN IPR AND} FDI

Before the enactment of modern intellectual property law in the 1980s, China's intellectual property protection system, which had been guided by the Soviet Union, experienced a period of change. Before 1992, China's intellectual property protection system can be roughly divided into five periods. In order to facilitate analysis, these five periods are divided into two large periods: before 1978 and after 1978 .

After the founding of the People's Republic of China in 1949, and immediately after August 1950, the Chinese government, in line with the principles of developing production, encouraging innovation, and respecting knowledge, promulgated three special documents and regulations on patent, trademark and publication management, thus laying the foundation for the new Chinese intellectual property protection system. On the issue of foreign investors applying for trademark registration, the Provisional Regulations on Trademark Registration provides that: "Citizens of countries that have established diplomatic relations with the People's Republic of China and entered into a contractual agreement may apply for registration in accordance with the provisions of these Regulations if they wish to use a special trademark." In 1963, in order to strengthen trademark management and promote product quality, the Chinese Government adopted the Trademark Management Regulations (known as the Trademark Regulations of 1963), which were promulgated and can be considered to have moved beyond the narrow level of the Provisional Patent Regulations of 1950. From 1967 to 1977, the intellectual property system collapsed completely as a result of the Cultural Revolution. It can be seen that in 1978, although China's intellectual property protection system has been initially established, and in some areas achieved remarkable results, but because of the ideological differences between East and West, this period has little technology transfer and foreign capital inflows.

The Third Plenary Session of the Eleventh Central Committee is the starting point of China's reform and opening up policy. In 1979, the Sino-US Trade Relations Agreement provided that China would use international standards on intellectual property rights to protect products exported to China by U.S. companies. Great strides have been made in the implementation of intellectual property law. Since 1980, China has also joined a number of international organizations on intellectual property rights. For example, accession to the
World Intellectual Property Organization in 1980, the Paris Convention in 1984, the Madrid Conventions and Washington Conventions in 1989, the Berne Convention and the World Copyright Agreement in 1992, the Geneva Convention in 1993 (on the protection of producers of phonograms from unauthorized reproduction of their phonograms), the accession of the Copyright Cooperation Agreement in 1994 and the recognition by the government of Beijing of compliance with the Agreement on Copyright International recognition of the Budapest Regulations on the Preservation of Microbials for Patent Procedures, the Locarno Agreement on the International Classification of Industrial Designs, the Geneva Convention for the Protection of New Plant Varieties and the Copyright Law Agreement 2000, among others.

With regard to domestic legislation, the Copyright Act was enacted in 1991, the Act on the Protection of Computer Software was enacted in 1991, the National People's Congress adopted penalties for copyright infringement in 1993 and 1994, China enacted a new Copyright and Trademark Law on 27 October 2001 to bring it into line with the TRIPS Agreement, and in August 2000, the National People's Congress adopted amendments to the Patent Law, which was implemented in July 2001. In addition, China has established special courts on intellectual property in Hainan, Guangdong, Fujian, Beijing, and Shanghai, established copyright databases in 1995 with the support of the German government's financial resources and personnel training, and some domestic universities, such as Peking University, Chinese Renmin University and Wuhan University. These universities have set up training institutions to provide intellectual property services to judges, lawyers, government IP officials and business people.

The Chinese government's efforts in intellectual property protection provided a favorable external environment for multinational companies to transfer technology to China. A strong IP protection system creates a favourable environment for foreign capital inflows and technology transfers, which boosted employment and economic growth (Kogut \& Zander, 1993; Tihanyi \& Roath, 2002). Yu (2007) conducted a survey of managers of foreign companies in China by found that multinationals were reluctant to transfer technical knowledge to local firms through licensing trade or technology transfer if local intellectual property protection was weak. They analyzed possible defensive measures by multinationals in situations where intellectual property protection is weak, such as transferring older technologies only to the other side of the joint venture, establishing a rigorous integrated supply chain to control quality and hide real technology. Inadequate intellectual property protection has also prevented multinationals from exporting goods to China or even producing them in China. In the 1990s, for example, China's lack of strict rules on the intellectual property rights of new varieties prompted international seed producers to agree to restrict the export of some seed varieties to Chinese farmers.

In our view, a general examination of FDI and IPR may not reveal a clear correlation between the two. Because FDI includes three basic investment models: joint venture, cooperative operation, wholly owned. Therefore, it may make more sense to observe the correlation between the three modes of IPR. To this end, we looked at changes in foreign 
direct investment from 1979 to 2003 . We can see that all three investment models tend to grow over time, with the growth of all types of investment relatively stable before 1992 and the largest increase in the contract amount of joint ventures and sole proprietorships from 1992 to 1993, while the contract amount of cooperative enterprises decreased sharply during this period. As we can see, the amount of investment in cooperative enterprises is decreasing year by year, while the investment in the other two forms is increasing. It is worth noting that after 1997, the investment of wholly owned enterprises has exceeded that of joint ventures since 1998 and tends to rise.

In the case of weak intellectual property protection, MNCs may be more willing to adopt a wholly sole proprietorship approach in order to "protect their reputation for quality" and may be more willing to adopt a wholly owned approach, and as intellectual property protection strengthens, MNCs may adopt alternative forms, such as cooperative enterprises and joint ventures (Du Pont, 2000). After the local government has established a better intellectual property protection system, strong intellectual property protection may ensure that the technology developed by the sole proprietorship enterprise is not infringed, so that the enterprise can obtain the rent generated by the technology monopoly (Ozawa, 1981). For multinational companies, taking the sole proprietorship enterprise in this case will be the best choice. The trends are consistent with our analysis in the previous section.

\section{POLICY IMPLICATIONS}

The large-scale spread of R\&D activities by MNCs to investment host countries is a new phenomenon of globalization in the past ten years. For the host country, especially a developing host country such as China, how to promote the spillover effect of TNC research and development institutions on the host country and curb its crowding-out effect is a new topic. There is not much international experience to learn from. Therefore, only by strengthening policy research and in-depth understanding of the motivation and law of the proliferation R\&D activities of MNCs can we formulate correct policies according to local conditions and guide the R\&D institutions of MNCs to play their role in enhancing the competitiveness of our economy to the maximum extent. Relevant government departments should pay full attention to policy research in this field. Specifically, the following strategies can be adopted.

\section{A. Establishing Technology Alliances with MNCs}

Chinese enterprises and MNCs should jointly conduct R\&D activities, and on this basis implement product production, management, and marketing. For example, Kangjia Electronics Co., Inc. has partnered with Lucent Technologies to develop mobile phones, and TCL Information Industry Group has partnered with Lotus to develop Internet services. While cooperating with multinational companies in R\&D activities, Chinese enterprises should make full use of the technical strength of multinational companies to improve the technological innovation level of enterprises and improve the technological learning and innovation ability of local enterprises through the exchange of basic technology, technical information, and other aspects, as well as joint undertaking of $R \& D$ projects with MNCs.

\section{B. Encouraging Universities, Research Institutions and MNCs to Establish R\&D Centers or Laboratories}

The purpose of establishing R\&D in China is to make the best possible use of local research and development resources, and to reduce development costs by carrying out extensive cooperation with Chinese universities and research institutions through project commissioning, joint R\&D, establishment of training centers, joint ventures, and joint ventures to establish joint research centers. Tsinghua University, for example, has established three research institutes, four laboratories and 12 training centers with wellknown MNCs. Through this type of cooperation, we can obtain a wide range of information and get the latest results.

\section{Improving the Level of $R \& D$ Activities and $R \& D$ Institutions}

While continuing to attract new $R \& D$ institutions of multinational companies, we should raise the level of foreign R\&D institutions. Host governments should encourage multinational companies to integrate their $R \& D$ institutions in China, so as to form a higher position in their parent company overseas R\&D institutions. For example, Ericsson integrated its six R\&D institutions in China, the formation of Ericsson China Research and Development Institute, which comprehensively improved Ericsson's research and development level in China. In addition, we should vigorously strengthen the protection of intellectual property rights, otherwise multinational companies will not be willing to engage in high-level research and development activities in China

\section{REFERENCES}

Azman-Saini, W., Baharumshah, A. Z., \&Law, S. H. (2010). Foreign direct investment, economic freedom and economic growth: international evidence. Economic Modelling, 27(5), 1079-1089.

Du Pont M. (2002). Foreign direct investment in transitional economies: a case study of China and Poland. ST. Martin's Press, LLC.

Kogut, B., \& Zander, U. (1993). Knowledge of the firm and the evolutionary theory of the multinational corporation. Journal of International Business Studies, 34(6), 516-529.

Long, M. A., Stretesky, P. B. and Lynch, M. J. (2018). Foreign direct investment, ecological withdrawals, and natural-resource-dependent economies. Society \& Natural Resources. 30(10), 1261-1276. DOI: 10.1080/08941920.2017.1331483.

Teece, D. J. (1997). Technology Transfer by MNCs: The resource cost of transferring technological know-how. Economic Journal, 87(6),242261.

Teece, D. J., Pisano, G. (1998). Collaborative Arrangement and Global Technology Strategy, Research on Technology Innovation, Management and Policy, In D. J. Teece (Eds). Selected works of David J. Teece (pp. 561-590). Edward Elgar Publishing Limited.

Tihanyi, L., Anthony, S, \& Roath. (2002). Technology transfer and institutional development in central and eastern Europe. Journal of World Business.37(3), 188-198.

Vernon, R. (1966). International investment and international trade in the product cycle.The Quarterly Journal of Economics, 80(2), 190-207.

Yu, P. K. (2007). Intellectual Property, Economic Development, and the China Puzzle. In Daniel J. Gervais (Eds). Intellectual Property, Trade and Development: Strategies to Optimize Economic Development in a TRIPs Plus Era, (1st ed, pp.173-220). Oxford University Press, Michigan State University Legal Studies Research Paper No. 04-23, Available athttps://ssrn.com/abstract $=978301$

Ozawa, T. (1981). Transfer of Technology from Japan to Developing Countries. New York: UNITAR. 
European Journal of Business and Management Research www.ejbmr.org

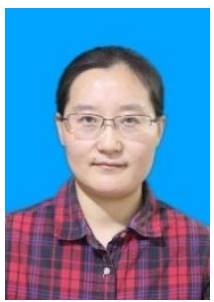

Dong-Mei Lee is an associate professor in the department of Accounting, School of Economics and Management, Shanxi University, P.R. China. She received his Master's degree from School of Mathematics, Shanxi University, P.R. China, and Ph. D in management from School of Economics and Management, Shanxi University, P.R. China. Her area of specialization is times series analysis, technology management and standard battles, data mining and machine learning.

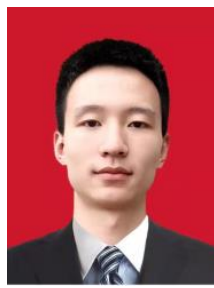

Lee-Yuan Wang is a postgraduate student in School of Economics and Management, Shanxi University, P.R. China. He received his B.A degree from Shanxi University, P.R. China. His current research interests focuses on innovation management, standardization, and machine learning.

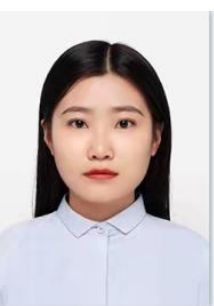

Yue Wang is a postgraduate student in School of Economics and Management, Shanxi University, P.R. China. She received his B.A degree from Shanxi University, P.R. China. Her current research interests focus on innovation management and standardization.

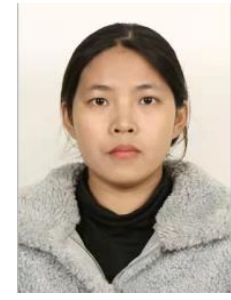

Dai-Jiao Zhou is a postgraduate student in School of Economics and Management, Shanxi University, P.R. China. She received his B.A degree from Henan University of Economics and Law, P.R. China. Her current research interests focus on innovation management and standardization. 